\title{
Residue Modification and Mass Spectrometry for the Investigation of Structural and Metalation Properties of Metallothionein and Cysteine-Rich Proteins
}

\author{
Gordon W. Irvine and Martin J. Stillman * \\ Department of Chemistry, The University of Western Ontario, London, ON N6A 3K7, Canada; girvine@uwo.ca \\ * Correspondence: stillman@uwo.ca; Tel.: +1-519-661-2111 (ext. 86358); Fax: +1-519-661-2111 \\ Academic Editor: Eva Freisinger \\ Received: 24 March 2017; Accepted: 20 April 2017; Published: 26 April 2017
}

\begin{abstract}
Structural information regarding metallothioneins (MTs) has been hard to come by due to its highly dynamic nature in the absence of metal-thiolate cluster formation and crystallization difficulties. Thus, typical spectroscopic methods for structural determination are limited in their usefulness when applied to MTs. Mass spectrometric methods have revolutionized our understanding of protein dynamics, structure, and folding. Recently, advances have been made in residue modification mass spectrometry in order to probe the hard-to-characterize structure of apo- and partially metalated MTs. By using different cysteine specific alkylation reagents, time dependent electrospray ionization mass spectrometry (ESI-MS), and step-wise "snapshot" ESI-MS, we are beginning to understand the dynamics of the conformers of apo-MT and related species. In this review we highlight recent papers that use these and similar techniques for structure elucidation and attempt to explain in a concise manner the data interpretations of these complex methods. We expect increasing resolution in our picture of the structural conformations of metal-free MTs as these techniques are more widely adopted and combined with other promising tools for structural elucidation.
\end{abstract}

Keywords: metallothionein structure; protein dynamics; cysteine modification; covalent labeling; ESI-MS; apo-metallothionein; metal induced protein folding

\section{Introduction}

Structure is of critical importance, whether it is in the design of buildings, writing of a poem, or in the function of proteins and other macromolecules [1-4]. Structure can be thought of not only as the position of elements within the whole, but also their rigidity and other individual properties that sum together to give molecular machines and engineers amazing abilities to build skyscrapers or catalyze key reactions required for life. It is because of the inexorably linked structure/function relationship that researchers devote extraordinary efforts to determine protein structure. From the crystallization of urease [5] to modern structure-predicting software [6], many tools have been developed in order to gain a glimpse into the microscopic world of protein structure.

Over billions of years, Nature has developed an immense catalogue of macromolecular structures that support and sustain life's essential processes. This diversity of protein structure has necessitated the development of numerous characterization techniques each able to be applied to only certain types and sub-sets of proteins. Typical characterization techniques include: X-ray diffraction from crystals, nuclear magnetic resonance (NMR) spectroscopy, electron microscopy, and small angle X-ray and neutron scattering. Due to the limitations of these techniques for molecules in solution, sophisticated mass spectrometric methods have been developed to investigate protein structure including hydrogen/deuterium (H/D) exchange, tandem mass spectrometry, ion mobility 
mass spectrometry (IM-MS), and residue modification coupled with electrospray ionization mass spectrometry (RM-MS).

In this review we will summarize recent advances in the lesser known method, residue modification, for the determination of structure and metal-binding properties of the flexible and ill-defined metallothionein family. The RM-MS technique is particularly suited to the study of metallothioneins because of their lack of formal secondary structural elements and abundance of specifically modifiable residues.

\section{Metallothionein}

Metallothioneins (MTs) are a family of proteins, unique in their lack of aromatic amino acids [7], small size (typically less than $10 \mathrm{kDa}$ ) [8], high cysteine content $(\sim 30 \%)$ [9], and flexibility that allows them to adopt many configurations, and this unique flexibility allows MTs to form metal thiolate clusters with a variety of metals $[2,10]$. The lack of a rigid structure allows MTs to coordinate a number of metals including essential metals like zinc and copper [11], toxic metals like cadmium [12] and mercury [13], and exotic metals like uranium [14] and technetium [15]. This flexibility, while fundamental to their function, makes MTs extremely difficult to characterize structurally.

MTs exist in almost all forms of life from bacteria to more complex invertebrates and mammals but are curiously absent from the genomes of Cnidarians [16-19]. While structural diversity exists for the many MTs in these divergent kingdoms of life, most consist of two separate metal binding domains that form a "dumbbell" shape when in their holo-form [20]. While other recent reviews have summarized advances in the characterization of plant, bacterial, and other non-mammalian MTs [2,21,22], we will focus on mammalian MTs.

Mammalian MTs have four main isoforms: MT-1 and MT-2 expressed constitutively with a higher content in liver and kidneys [23,24], MT-3 expressed mainly in the brain and central nervous system [25], and MT-4 expressed in cornified, stratified, squamous epithelium, a protective tissue found on many organs including the skin, tongue, and vagina [26]. The conserved sequences between the mammalian isoforms contain the 20 cysteines that are essential for metal binding, Figure 1.

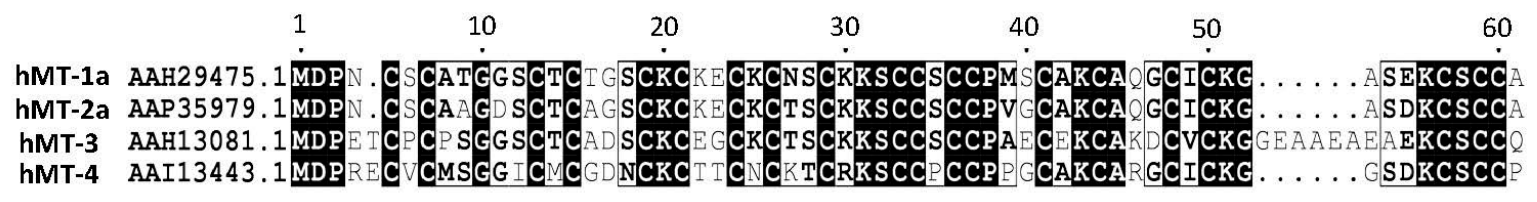

Figure 1. Clustal Omega sequence alignment of the major human metallothionein isoforms with conserved amino acids highlighted in black. Generated with ESPript 3.0.

\subsection{Biological Function}

Metals in biological systems are tightly controlled [27]. "Free" metal ions can lead to harmful side reactions, or can be scavenged by pathogens [28,29]. MTs are part of a complex network of proteins, metallochaperones, that are involved in the transport and storage of essential metals and maintenance of metal homeostasis [30,31]. MT has been shown to directly donate zinc to metallo-enzymes like carbonic anhydrase [32] and drive copper to cellular locales by a binding affinity gradient [33]. Knockout studies of mice MT-1/2 genes produce mice unable to tolerate the influx of toxic metals that alter this homeostasis, although the deletion is not fatal in the absence of these toxic metals [34-36]. The deletion of these genes significantly decreases the ability to adapt to sub-optimal environmental metal concentrations [37-39]. 
Toxic metal sequestration is another proposed biological function of MTs. It is clear that MT confers a protective effect against cadmium intoxication [40,41]; MT was first isolated as a cadmium containing protein in an equine renal cortex [42,43]. In addition to cadmium, MT has been shown to bind arsenic under a wide variety of conditions [44-48] and to be associated with protection against arsenic related cancers [39,49-51], although isolation of As-MT species from in vivo studies remains elusive [52]. MT-3, the brain-specific isoform, has been shown to bind neurotoxic metals such as lead [53] and interact with proteins associated with neurodegenerative diseases [54-56]. In addition to homeostatic maintenance, it has been suggested that MTs having 20 free-SH thiols, contribute to redox signaling, and balance within the cellular environment [57-59]. RM-MS leverages the abundance of reactive thiols on MT to probe its solution structure without the need for high concentrations or crystallization. As MTs play a role both in the proliferation of tumors and resistance to chemotherapy, much interest has been given to analytical methods to detect and quantify MTs in biological samples [60,61].

\subsection{Structural Characterization of MT in Various Metalation States}

Our knowledge of the MT protein structure comes mainly from NMR studies, as this protein has been notoriously difficult to crystallize. The two X-ray crystal structures are of rat liver $\mathrm{Cd}_{5} \mathrm{Zn}_{2}$-MT-2 and yeast $\mathrm{Cu}_{8}-\mathrm{MT}$, both fully metalated species of MT $[62,63]$. Much of the NMR data is of the fully metalated species of human and rat isoforms, especially with ${ }^{111,113} \mathrm{Cd}$ [64-66]. Attempts to determine partially-metalated $\left(\mathrm{Cd}_{2.9} \mathrm{MT}-2\right)$ structures by NMR were only successful at lower $\mathrm{pH}$, where we now know that cooperative cluster formation occurs [67], giving sharp distinct peaks compared to higher $\mathrm{pH}$ where a single broad undistinguished peak was observed [68]. Thus, NMR techniques are only useful when a stable metal-thiolate cluster has formed, even when only partially metalated [68] or supermetalated [69]. Under normal homeostatic conditions and at physiological $\mathrm{pH}$, it is unlikely that MT would be able to form such stable clusters due to the constant shuttling of metal ions to higher affinity catalytic and structural sites on other metalloproteins. To obtain a better picture of the structure-function relationships of MT, more exotic techniques must be employed to probe the structure for the metal-free or partially metalated species.

\subsection{Optical Techniques for MT Structural Determination: Circular Dichroism, UV-Visible Absorption, and Emission Spectroscopy}

Optical techniques for investigating protein structure have been available for a long time and have been used extensively to characterize MT and its interactions with a variety of metals [70]. MT's lack of aromatic amino acids limits the usefulness of far-UV absorption spectroscopy to investigate metalation status via the ligand-to-metal charge transfer band [71]. Even with drastic structural changes upon "supermetalation" with cadmium, the absorption spectra is relatively unchanged because the ligand-to-metal charge transfer (LMCT) chromophores are so similar that the superposition of the absorbance from the individual metal sites means that only an averaged spectrum is recorded [69]. Circular dichroism spectroscopy is more sensitive to structural changes, especially those that disrupt the symmetry of the metal-thiolate cluster and change the exciton coupling. This coupling results in a crossover point at $250 \mathrm{~nm}$, the absorption maximum of the Cd-thiolate LMCT band. When the coupling is disrupted, meaning MT is either partially or super-metalated, the absorption maximum shifts to $250 \mathrm{~nm}$ and the crossover point to $240-245 \mathrm{~nm}$ as the symmetry dependent exciton coupling is lost. For emissive species like $\mathrm{Ag}$, $\mathrm{Au}$, or $\mathrm{Cu}-\mathrm{MTs}$, emission spectroscopy is useful in determining structure as solvent access to the thiolate clusters quenches the emission and provides information on the compactness of the protein conformation [72-74].

As we note above, these optical techniques are limited in their power for structure resolution for multi-metal binding MTs because they give an average response of all the species in solution. Also, these optical techniques are less useful for the spectroscopically silent zinc, perhaps the most biologically relevant metal that binds to MT and the one most commonly isolated for biological samples. When a distribution of multiple species is present, spectral features cannot be assigned to any one 
species. For example, when 2 mol eq. of $\mathrm{Cd}^{2+}$ are added to $\alpha$-MT- $1 \mathrm{a}$, which can bind up to four divalent metals, apo- and $\mathrm{Cd}_{1-4} \alpha-\mathrm{MT}$ are all present in varying amounts depending on $\mathrm{pH}$ conditions [67]. Mass spectrometry on the other hand can distinguish between each species that is present and measure their relative abundance which, when coupled with optical spectra, can accurately assign spectral features to specific MT species. In addition, techniques like ion-mobility mass spectrometry (IM-MS), tandem mass spectrometry (MS/MS), and residue modification mass spectrometry (RM-MS) can help to provide insight into the MT structure in apo-, holo-, and partially metalated states.

\section{Mass Spectrometry for Structural Determination}

Since the development of soft ionization techniques like electrospray and matrix assisted laser desorption/ionization (MALDI), the use of mass spectrometry in the field of protein structure and dynamics has grown exponentially. Unlike optical techniques, which examine global properties and observe an average response of all species present, MS techniques can simultaneously give information on species distribution and relative abundance, protein volume, surface area, and conformational changes via charge states [75], and information about specific regions within the protein and their solvent exposure via hydrogen/deuterium exchange (HDX) [76] or site specific covalent modification [77]. HDX is suited for larger proteins, with an extensive H-bonding network between backbone amide hydrogens which limits the rate of association/dissociation, resulting in a smaller mass change compared with disordered regions and those that are more solvent exposed. These techniques are reviewed in detail elsewhere [78].

\section{Covalent Modification}

A common criticism concerning the use of ESI-MS for the analysis of protein structure and conformation lies in the radically different surroundings the protein finds itself in when being analyzed compared to its native state. The native state, in solution, is buffered around neutral $\mathrm{pH}$ with an appropriate salt concentration, at approximately $37^{\circ} \mathrm{C}$ and absent of chemical denaturants. The conditions of the electrospray process introduce high voltages, evaporating solvents causing a hyper-accumulation of salt ions and, finally, ionization of the protein itself and transition into a gas phase ion. The assumption that the conformations adopted in solution and under ESI conditions are the same may be a tenuous one.

An advantage of covalent modification is that it probes the conformation under solution conditions and changes thereafter during analysis and measurement of the gas phase ions have no effect on the modifications that occur prior to ionization. This is especially important for proteins whose structure is unstable and whose solution stabilized conformation may not reflect those conformers adopted during the electrospray process.

\subsection{Covalent Modification to Identify Free Thiols}

Cysteine is an important amino acid with high reactivity [79], able to coordinate a variety of soft metals [80], and form Cys-Cys covalent linkages that add stability to folded proteins [81]. Cysteine is also used to attach therapeutic and imaging moieties to proteins in vivo [82]. Covalent modification coupled with mass spectrometry can easily identify free cysteinyl thiols versus those that are oxidized to form crosslinks. New proteomic strategies also make use of specific covalent modifiers coupled with LC-MS and MS/MS to identify S-sulfenylation of cysteines and identify the most solvent exposed residues [83]. The redox chemistry inherent in quinones has been used for on-line tagging of free cysteines in ESI-MS analysis via a 1,4-Michael addition [84]. With the incorporation of a photo-active quinone, the protein backbone can be selectively fragmented with ultraviolet light for the analysis of solution structural properties or to monitor biological quinone post-translational modifications [85]. This technique can also be applied to other amino acids by leveraging thiol chemistry to selectively modify phosphorylated serine or threonine residues [86]. 
In the case of MTs, determining the number of free thiols under an assortment of different metal coordination numbers and geometries can help in structural determination. This is because the number of free thiols can be a good indicator of metal-cysteine cluster formation, as clusters involve bridging thiolates and, as a result, more metal ions can be coordinated with a smaller number of cysteine residues. Terminally coordinated metals require more cysteinyl thiols in MT and are considered to be more labile and thus available for donation to other metalloenzymes [67]. Also, when probing potentially new structures formed by the coordination of unusual metals and metalloids where the stoichiometry is not defined, the quantification of free thiols by cysteine modification and ESI-MS can establish defined Cys:Metal ratios [87].

Arsenical binding to metallothionein first reported by Le and coworkers [46] was characterized kinetically for free As(III) [45] and first reports indicated a stoichiometry of the fully saturated protein as an $\mathrm{As}_{6}$ species $[46,88]$. However, the coordination was only speculated upon, with As(III) unique in possessing a non-bonding electron pair, which likely forces the protein to adopt six tri-coordinate metal centers using 18 cysteinyl thiols and leaving two free-SH groups in human metallothionein. This was confirmed later by cysteine modification, and the $\mathrm{As}(\mathrm{SCys})_{3}$ structure formed for all intermediates $\left(\mathrm{As}_{1-5}\right)$ in the metalation reaction as well, indicating the absence of bridging thiolates typical of metallothionein clusters [87].

During the non-cooperative metalation of metallothionein, a number of species are present simultaneously in solution with different numbers of bound metals, resulting in mass spectra with, usually, a normal distribution of peaks separated by the mass of the metal, as seen in Figure 2. Figure 2B,D show the distribution of As(III) bound to the $\alpha$-domain of human metallothionein 1a at different points in the metalation reaction. Figure $2 \mathrm{C}$ shows the result of adding excess quinone, in this case $p$-benzoquinone (Bq), to the mixture where all free cysteine residues have been modified. Each peak (corresponding to the modified apo- and $\mathrm{As}_{1-3}$ species) is separated by the mass of three Bq molecules, indicating each $\mathrm{As}(\mathrm{III})$ is being coordinated by three cysteinyl thiols. When a different distribution of metalated species (Figure 2D) is modified, the result is the same (Figure 2F). This result indicates that the coordination of As(III) is fixed and does not adopt multiple geometries as in the case of $\mathrm{Cu}$ (I) binding to MTs. While $\mathrm{Zn}$ (II) and $\mathrm{Cd}$ (II) have fixed geometries, cluster formation via bridging ligands alters the ratio of bound vs. free thiols (i.e., $\mathrm{Cd}_{4}(\mathrm{SCys})_{16}$ in terminal "beaded" structures vs. $\mathrm{Cd}_{4}(\mathrm{SCys})_{11}$ in clustered structures) [89].

Figure 2 also highlights the power of ESI-MS for resolving multiple species present simultaneously in solution, even without the aid of chromatography as in GC-MS or LC-MS. Optical spectra may show global solution property changes due to the attachment of $\mathrm{Bq}$ to the protein but the number of species in Figure 2E would not be distinguished. A total of eight species, each with a unique mass due to differential metal loading and modification status, are easily resolved. In the data presented in Section 4.2, an even greater number of species is resolved in the ESI mass spectra.

The abundance of reactive thiols in apo-metallothioneins have been exploited in electrochemical studies [90], for functionalization and tethering of gold nanoparticles [91] and for their colorimetric detection [92]. The thiol-quinone reactivity has also been used to probe the structural properties of these hard to characterize proteins [93]. In addition to simple quantification of free thiols, covalent modification can be used to probe the structure and relative solvent exposure of specific residues in proteins that contain multiple cysteines. 


\section{As- $\alpha-r h M T$}
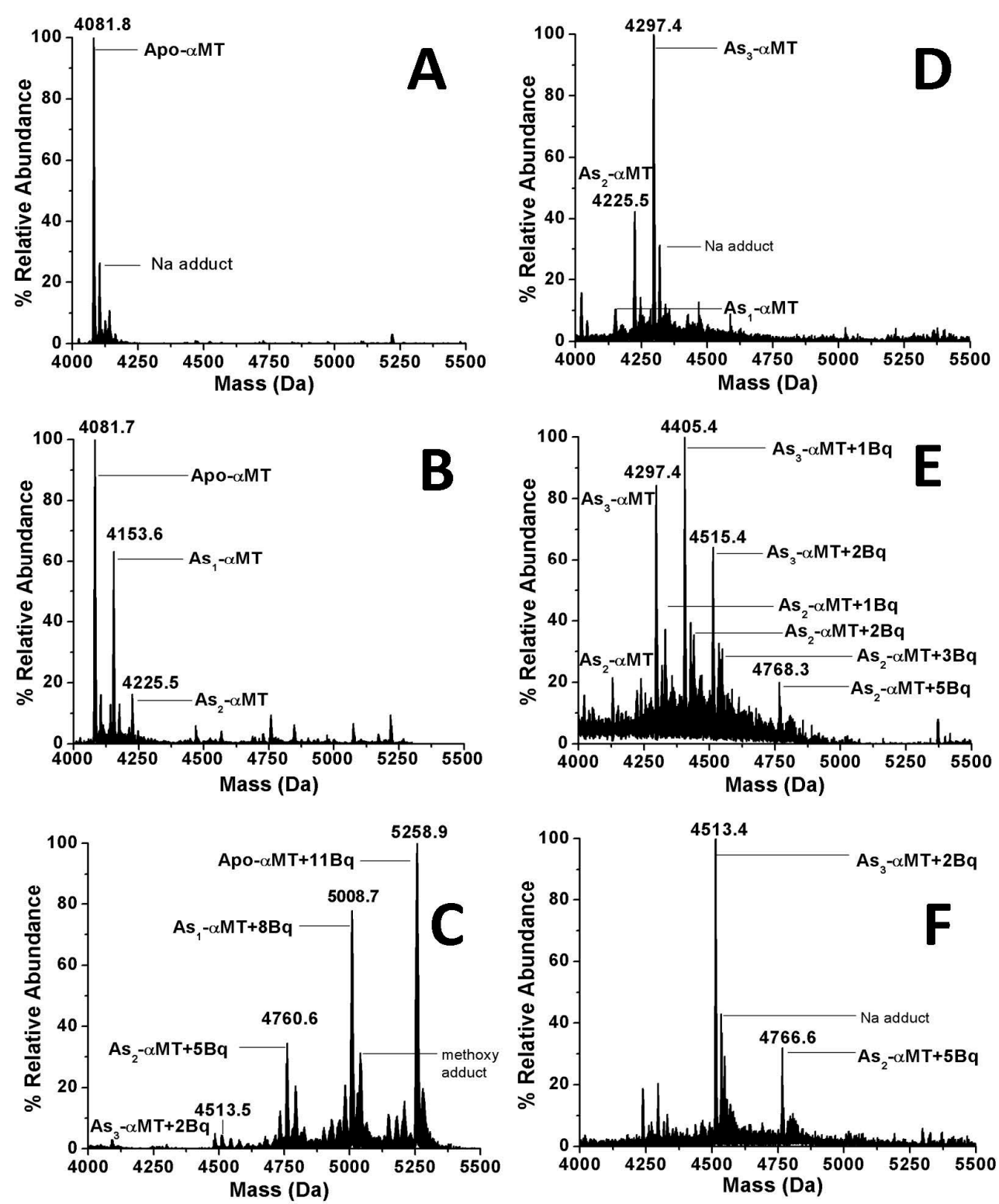

Figure 2. Deconvoluted electrospray ionization mass spectra (ESI-MS) of Arsenic-MT species $\left(\mathrm{As}_{0-3}-\alpha-\mathrm{MT}-1 \mathrm{a}\right)$ covalently modified by $p$-benzoquinone (Bq). (A) Metal-free protein; (B) Partially metalated $\alpha$-MT with As(III) with a large fraction of apo-protein; (C) Species in 1B fully modified by excess Bq; (D) Partially metalated $\alpha$-MT with a larger fraction of saturated As $s_{3}-\alpha$-MT; (E) Addition of 2 mol eq. of Bq to the species in 1D; (F) Species in 1D fully modified by excess Bq. Reproduced with permission from Irvine et al., 2013 [87].

\subsection{Free Thiol Modification to Probe Domain Specificity in Metallothioneins}

Domain specificity is a concept that has long been investigated in the case of metallothioneins with its two-domain structure consisting of a smaller, 9 cysteine $\beta$-domain and a larger 11-cysteine $\alpha$-domain [94-98]. Domain specificity has been primarily investigated by NMR spectroscopy [95] and ESI-MS $[98,99]$ due to the ability of both techniques to identify the domain in which the metal is bound. This has led to reports of certain isoforms and domains having specific metal binding properties, resulting in some isoforms and domains labeled as being metal-specific $[97,100,101]$. 
Conclusions reached from these in vitro studies were based on the metal binding constants and apparent metal preferences during titration. Attempts to study isoform and domain-specificity in vivo are hampered by the low concentrations, difficulty of extraction, and the ease of introducing and changing the metal distribution in the metallothionein during purification protocols. For example, over-expression of mammalian MT-3 in a recombinant system and supplementation of growth media with $\mathrm{Cu}(\mathrm{I})$ can lead to an apparent $\mathrm{Cu}$-thionein character [97], although it is unclear how significant the MT-3 preference for $\mathrm{Cu}(\mathrm{I})$ would be in mammalian brain cells, with normal $\mathrm{Cu}(\mathrm{I})$ concentrations and with other competing $\mathrm{Cu}(\mathrm{I})$ binding proteins [54]. RNA expression of MT-3 was shown to be unaffected by $\mathrm{Cu}(\mathrm{I})$ supplementation in epithelial cancer cells, although cell type has a large influence on isoform expression [102]. Domain specificity presents a larger challenge, since RNA analysis cannot give information about intra-protein selection in response to metal stimuli. To address these questions, isolated domain competition experiments can be performed, although the elimination of the inter-domain linker raises questions about the strength of the chelate-effect of the entire protein and the barrier to cross domain metal exchange introduced by the separation of these domains in solution [98].

To determine the arrangement of metals in partially-metalated MTs without using isolated domain fragment experiments, the covalent modification of free thiols can be used in the full-length protein. In work by the Russell group, ESI-MS, covalent labelling with $N$-ethylmalemide (NEM), and IM-MS/MS was used to show MT-2a preferentially forms cadmium-thiolate clusters in the $\alpha$-domain in both metalation and demetalation reactions [103]. Although some isoform-specific differences likely exist, MT-1a cooperatively forms cadmium clusters in the $\alpha$-domain and this has been reported in both the full-length protein and the isolated $\alpha$-domain fragment $[67,89]$. In competition experiments, a slight preference for $\alpha$-domain metalation is observed that is exaggerated at lower $\mathrm{pH}$ [98]. Thus at least for the MT- $1 / 2$ isoforms cadmium metalation is $\alpha$-domain specific, a phenomenon that becomes more apparent at lower $\mathrm{pH}$.

In addition to cadmium and arsenic metalation, covalent modification was used to probe the structures adopted during $\mathrm{Cu}(\mathrm{I})$ metalation of the MT-1a isoform. The multiple geometries that $\mathrm{Cu}(\mathrm{I})$ can adopt in MT with 20 available Cys-ligands makes structural characterization extremely difficult. Like the other MTs, the only crystal structure reported to date is that of the metal-saturated form and, for $\mathrm{Cu}(\mathrm{I}) \mathrm{MTs}$, only for yeast-MT which is saturated as $\mathrm{Cu}_{8}-\mathrm{MT}$, whereas, the mammalian isoforms can accommodate up to $20 \mathrm{Cu}$ (I) ions. Recently, the metalation and folding pathway of $\mathrm{Cu}(\mathrm{I})$ metalation of apo-MT1a was probed using emission and CD spectroscopy, and ESI-MS coupled with covalent modification by $p$-benzoquinone (Bq). Through emission and CD spectroscopy, the overall conformational changes were monitored and ESI-MS helped to identify the metal coordination number and distribution of species that gave rise to the optical spectra. These data allowed identification of species that correspond to known cluster structures and the modification of free thiols proved that the $\mathrm{Cu}_{6}$ cluster was formed in the $\beta$-domain and the $\mathrm{Cu}_{10}$ species consists of the $\mathrm{Cu}_{6}$ cluster in the $\beta$-domain and a $\mathrm{Cu}_{4}$ cluster in the $\alpha$-domain (Figure 3 ). This domain specificity showed different $\mathrm{pH}$ dependence than that of cadmium, where cluster formation was most dominant between $\mathrm{pH} 5.3$ and 7.4 and followed a more non-cooperative, terminally bound pathway above and below this range.

RM-MS is not particularly suitable for probing differences between MT isoforms, as long as those isoforms have identical numbers of cysteine residues and bind metals with the same Cys-metal stoichiometry. These major differences are unlikely between structurally similar isoforms from mammalian species, the major inter-isoform difference is considered to be with metal preference and spatial distribution biological context [104,105]. The mammalian MT family is considerably less diverse than amongst other biological strata [106]. Interestingly, ionization efficiencies vary widely between the similar mammalian MT isoforms, and even between the two domains of MT1a which require external concentration verification in competition and affinity experiments $[32,98,107]$. 

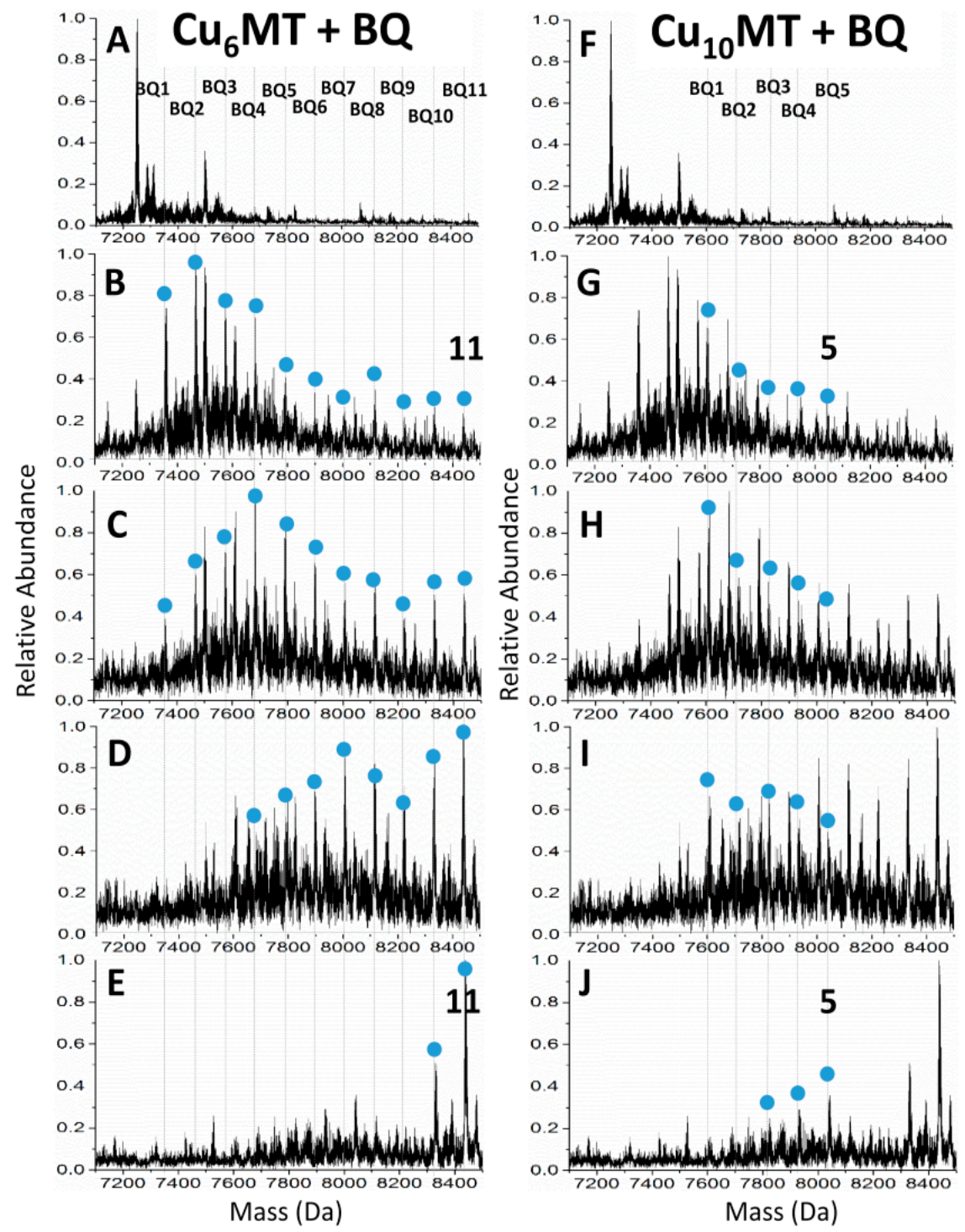

Figure 3. Free cysteine modification with $p$-benzoquinone of a Cu-MT solution containing mainly $\mathrm{Cu}_{6}$ and $\mathrm{Cu}_{10}-\mathrm{MT}$ species. Both columns show the same spectra with different peaks labeled and highlighted with blue dots. Bq modified species for $\mathrm{Cu}_{6}-\mathrm{MT}$ are shown in (A-E) and the modified species for $\mathrm{Cu}_{10}-\mathrm{MT}$ are shown in $(\mathbf{F}-\mathbf{J})$. Reproduced from ref. [108] with permission from the Royal Society of Chemistry.

\subsection{Covalent Modification to Probe Solution Structure and Protein-Protein Interactions}

Modification of reactive residues has proven in the past to be a useful albeit mostly low-resolution tool to probe the structures of hard to characterize proteins, this method being another tool in the arsenal of techniques that are needed to piece together an understanding of how ill-defined proteins behave. One strategy is to use cross-linking reagents to tether two interacting proteins together. Once connected by the linker, the dimer can be proteolytically digested or fragmented via tandem MS and analyzed to identify the residues which participated in the cross-linking and thus were likely involved in the protein-protein interaction [109].

In addition to chemical cross-links, analysis of modification patterns can be helpful in identifying protein-protein interactions in peptides where many residues can be modified, like MTs. In cases where all modifiable residues (in the case of MTs, cysteine) are equally accessible by the modifying agent, the result will be a normal distribution of modified species (Figure $4 \mathrm{~A}$ ). Where unequal access 
exists, an altered pattern of modification will exist. This is exemplified in Figure 4B,C. At low pH most proteins denature and this can be easily monitored by optical methods with the loss of secondary structure or via ESI-MS in the appearance of higher charge states. Because of MT's small size, the shift in charge states is minor and due to its lack of secondary structural features in the absence of metals, no change in the optical spectra is observed. The modification profile however follows a stochastic distribution, indicating equal access to all cysteine residues. Arsenic metalation of MTs is unique in that it metalates even at low $\mathrm{pH}$, albeit at a slow rate able to be monitored by ESI-MS [45].
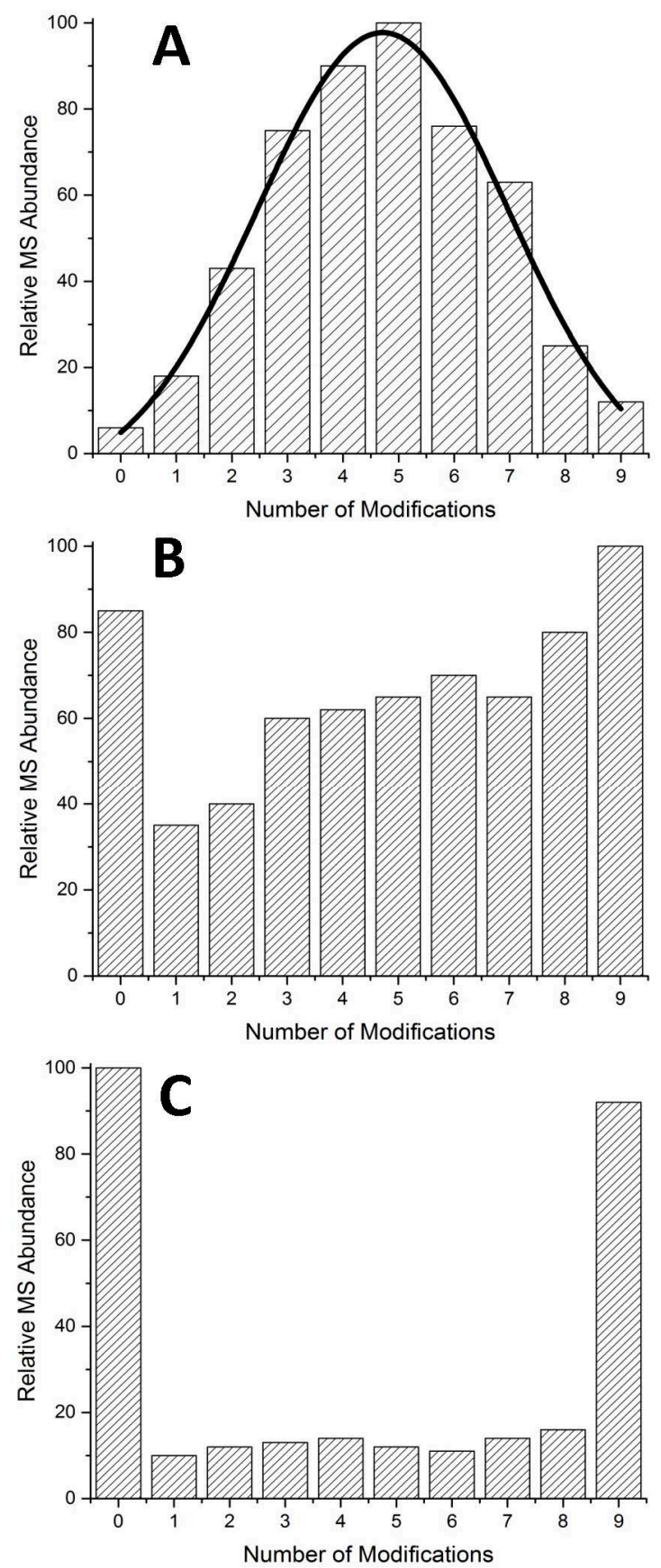

Figure 4. Examples of possible modification distributions in typical mass spectra. (A) Normal distribution of modified species where small amounts of apo- (0 modifications) and fully modified species (9 modifications) exist simultaneously; (B) semi-cooperative pattern, has significant amounts of the apo-species, intermediates (1-8 modifications), and fully modified species; (C) cooperative pattern, where few intermediates exist and the spectra is dominated by the apo- and fully modified species. 
In the presence of $\mathrm{As}(\mathrm{III})$ ions, even at low $\mathrm{pH}$, the modification profile of the partially-metalated species shifts drastically to one that can be described as semi-cooperative [44]. That is, the unmodified species exists in solution in roughly equal amounts as all partially modified species, up to species where all free cysteine residues not involved in As(III) coordination are covalently bound by Bq. This is an indication that even under denaturing conditions, the introduction of a coordinated metal ion induces the folding of MT that creates unequal solvent access to some free cysteine residues. This result is not unexpected as it is well known that the introduction of metals creates a more rigid structure even if only partially-metalated [71,110]. What is surprising about the data is that the modified apo-MT species follow the same pattern.

The semi-cooperative pattern of modifications of the apo-MT species is highlighted in Figure 5. Again, this indicates that the cysteine residues in apo-MT, where no metal is coordinated, are differentially shielded by some means. Since the reaction was carried out, and mass spectra recorded, under denaturing conditions, it is not the native folding that is causing the unequal access and resultant modification profile. The exchange of As(III) ions between proteins in solution is a slow process and the residual structure left after As(III) has left is likely to be very short-lived under denaturing conditions. A more plausible explanation is that protein-protein interactions facilitated by As(III) coordination causes certain cysteine residues to be shielded from the bulk solution and therefore are unavailable for modification.

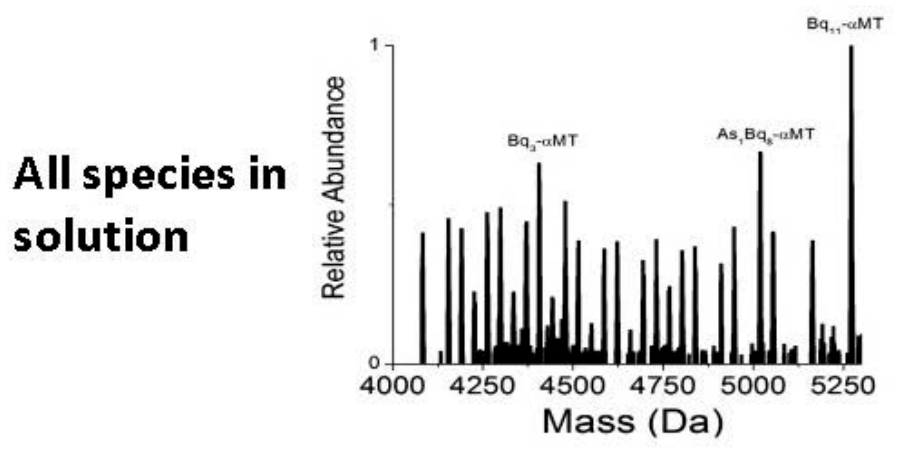
$A s_{1}-M T$ and
Bq modified species

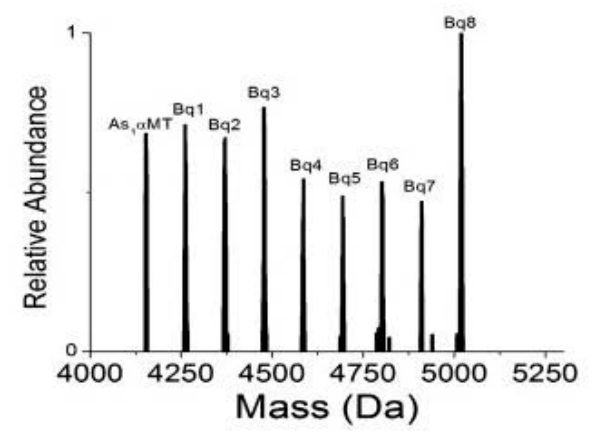

\section{$\mathrm{As}_{2}-\mathrm{MT}$ and \\ Bq modified species}

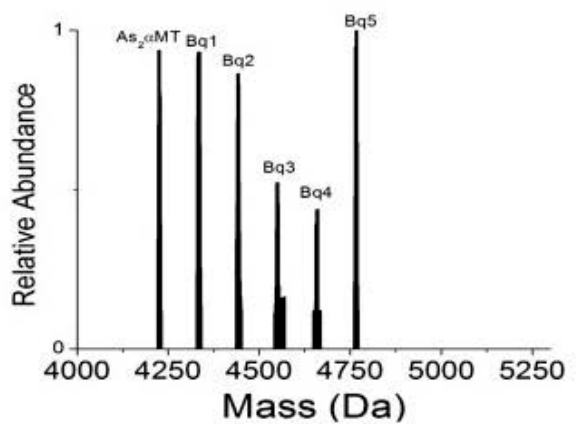

Figure 5. Cont. 


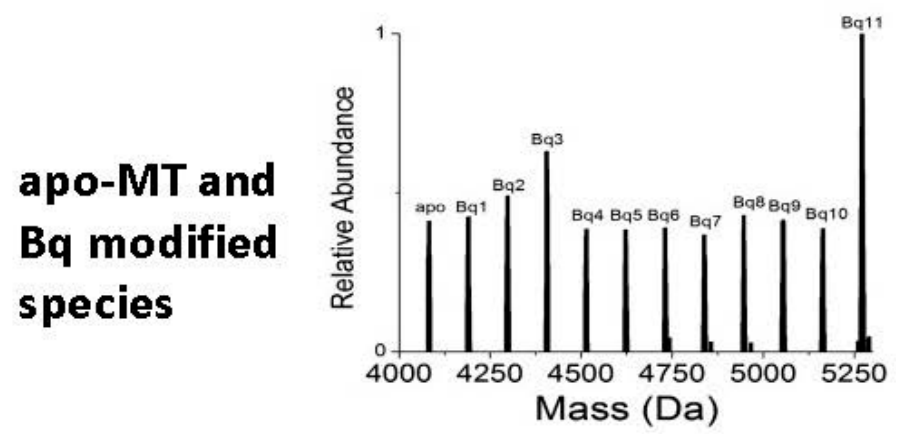

Figure 5. Modification of apo- $\mathrm{As}_{1}$ and $\mathrm{As}_{3}-\alpha \mathrm{MT}$ solution with $p$-benzoquinone (Bq). The original spectra after modification is shown at the top. The individual species and their modifications are isolated from the top spectra and are shown below in the left column. Adapted with permission from Irvine et al., 2013 [44].

The results from the cysteine modification experiments highlight the importance of metal coordination to MT folding, even under extreme conditions. Previous experiments showed that As(III) transfer between MT proteins must proceed via a direct transfer rather than a dissociative/associative mechanism [47]. The cysteine modification experiments was able to probe the interactions in solution and was easily measured via ESI-MS. While the results are at times difficult to interpret, a simplified way to examine the data is to always compare the modification to a normal distribution of modified species. Any deviation indicates the differential shielding of cysteines within the protein with larger deviations pointing towards large discrepancies between individual cysteine residues in terms of solvent accessibility.

\section{Probing Protein Conformation via Differential Modification}

The conformation adopted by MT, one that is fluxional and ill-defined, has been shown to be essential for metalation kinetics [111]. This is somewhat counter-intuitive, since a more open conformer where the cysteine residues are most exposed to the solvent and incoming metal ions might be expected to metalate faster. However, key to the metalation mechanism of MTs, especially when binding cadmium, is the formation of cadmium-thiolate clusters which involve both bridging and terminal cysteine residues. The more compact conformer(s) found under native conditions, while they may not represent all conformers found under these conditions [110], likely orient the cysteine residues in a way that is "primed" for metal binding and cluster formation. That is, the cysteine residues are aligned so that the bridging cysteines are in, or close to, the optimal position to form a bridging bond between two cadmium ions. Once formed, the cadmium-thiolate cluster is known for its stability and amenability to determination by ${ }^{113} \mathrm{Cd}$ NMR and other methods.

To better understand the origin of these differential modification patterns, the reaction can be modeled using a series of sequential, bi-molecular reactions which can give simulated mass spectral data that include species abundances at different points in the reaction. When the modeled Ks of the reaction reproduce the experimental mass spectra to a high degree of similarity, the relative values of the Ks can be compared and conclusions can be drawn. In the case of the differential modification of $\alpha$-MT-1a by Bq, the Ks revealed a series of declining values under denaturing conditions which is expected as the loss of binding sites as the reaction proceeds results in the statistical decrease of binding constants. Under native conditions, the relative constants do not decrease but increase slightly. This can be explained by the opening or denaturation of the compact conformers by the modification of cysteinyl thiols by the bulky Bq molecule. There are two major factors in addition to the intrinsic chemical nature of the reaction that govern the rate at which cysteine residues are modified: 
(1) The statistical availability of free thiols. During the early stages of the modification of a peptide, the abundance of free thiols makes a reaction more likely since there are more "binding sites" for the modification reagents. Since there are more places on the protein that are capable of reaction, a successful collision between a free cysteine and an alkylation reagent is more likely. As the cysteine residues are modified, the likelihood of a successful collision decreases due to the increasingly rare potential reaction sites on the protein.

(2) The steric accessibility of free thiols. It is well-known that the semi-hydrophobic nature of cysteine allows for marked differences in solvent accessibility depending on the folded state of the protein [112-115]. The more solvent that has access to these residues, the faster the reaction rate [112]. During the modification reaction of MTs, the compact conformer extends, exposing previously buried residues and increasing their solvent accessibility and therefore, the rate of modification. This is likely the origin of the semi-cooperative nature of the modification reaction of MTs under native conditions.

Questions then arise about the nature of the modifier and its effect on protein conformation and reaction profile.

In order to test differences in cysteine modification profiles, three common covalent cysteine modifiers were tested: $p$-benzoquinone (Bq), $N$-ethylmalemide (NEM), and iodoacetamide (IAM). These three modifiers have different sizes, hydrophobicities, and reaction mechanisms that are well characterized [116-118].

The two larger modifiers, NEM and Bq, resulted in very similar modification profiles (Figure 6). The origin of these cooperative-like patterns lies in the disruption of the native globular, random coil configuration by the large and more hydrophobic cysteine modifiers. The disruption of the compact confomer causes the remaining free cysteines to become more exposed to the solvent and more readily react with more incoming NEM or Bq molecules. Visual representations of these two conformers are presented in Figure 7 with the compact, globular conformation in Figure 7A and the extended conformation in Figure 7C.

Figure 7 shows the large change in conformation upon Bq modification under native conditions and the minor change under denaturing conditions. Under denaturing conditions, the protein already exists in an extended conformation and the modification of cysteine residues does little to change this, in contrast to the compact conformation where modification opens up the structure.
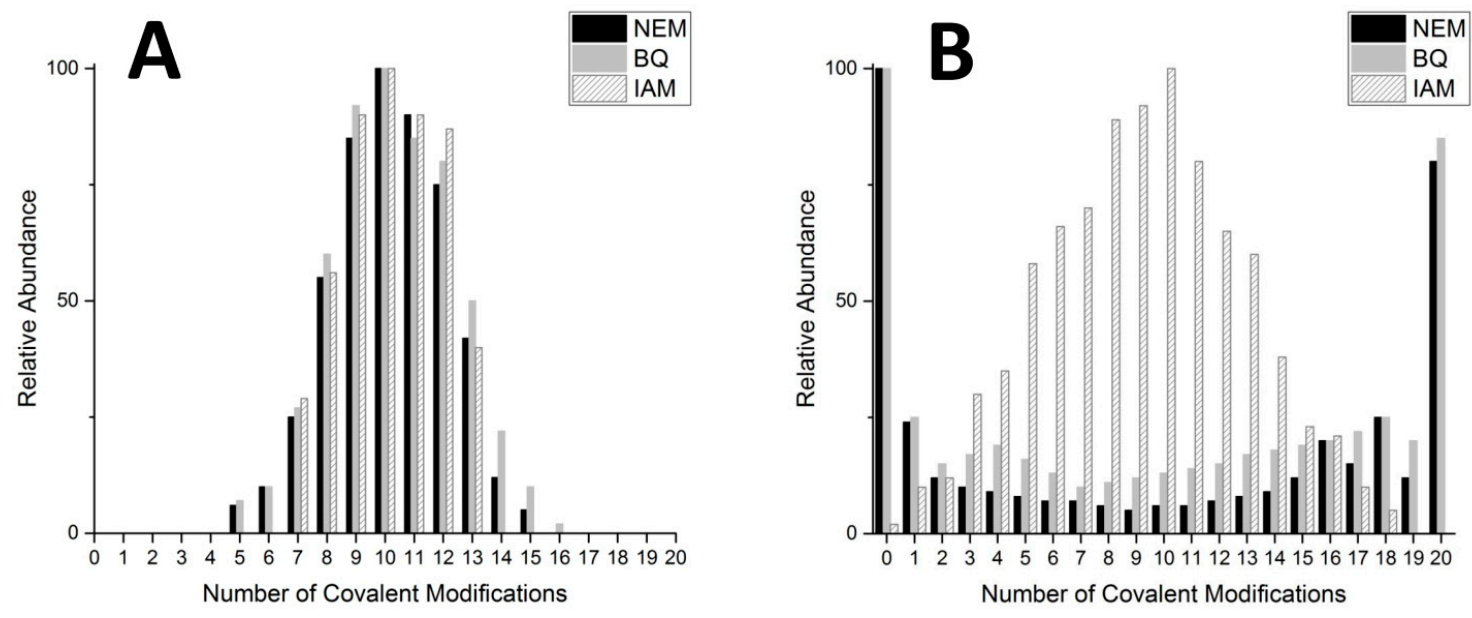

Figure 6. Modification profiles of $N$-ethylmalemide (NEM), $p$-benzoquinone (Bq), and iodoacetamide (IAM) cysteine alkylation reagents with $\beta \alpha$-MT-1a under denaturing (A) and native (B) conditions. Relative abundance taken from deconvoluted ESI-MS data after the reaction of $10 \mathrm{~mol}$ eq. of each of the modifiers. Adapted with permission from Irvine et al., 2017 [119]. 


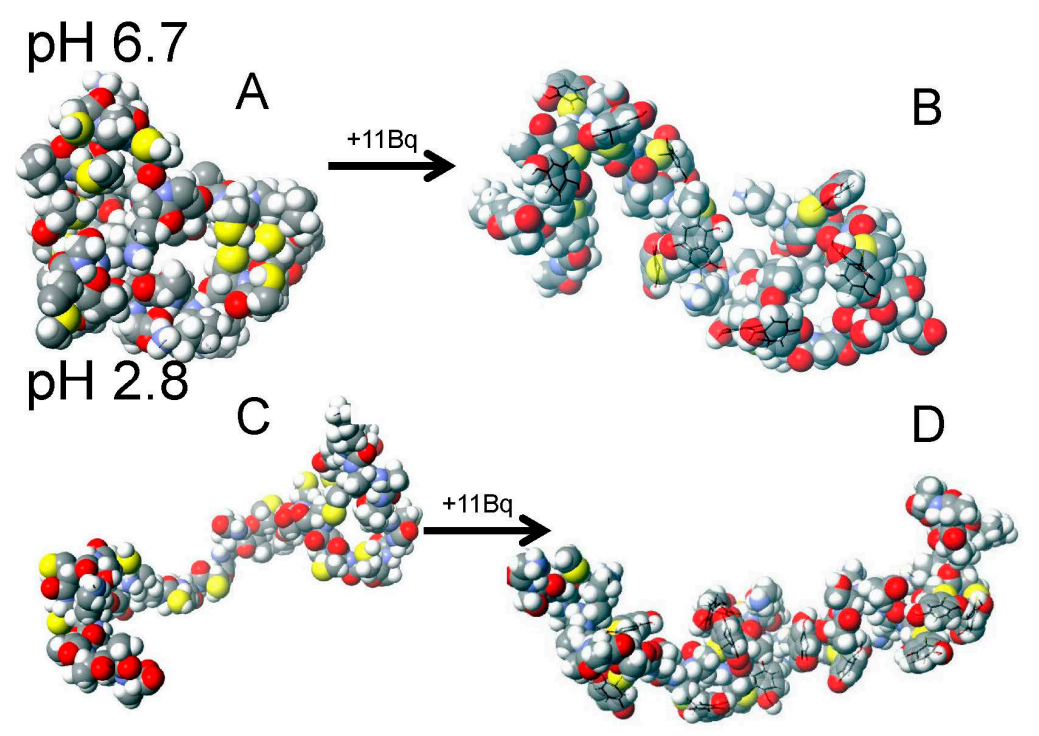

Figure 7. Molecular mechanics, molecular dynamics (MM/MD) simulation of energy minimized $\alpha$-MT conformations under native $(\mathbf{A}, \mathbf{B})$ and denaturing $(\mathbf{C}, \mathbf{D})$ conditions. Apo- $\alpha \mathrm{MT}$ is shown in $\mathbf{A}$ and $\mathbf{C}$ and fully modified $\mathrm{Bq}_{11}-\alpha-\mathrm{MT}$ in $\mathbf{B}$ and $\mathbf{D}$. Adapted with permission from Irvine et al., 2015 [111].

\section{Kinetic Data from ESI-MS and Cysteine Modification}

The data discussed in the previous section are essentially "snapshots" of the reaction; the progress reports that would be observed if excess modifier were added and ultra-high speed spectra recorded. Instead we used a step-wise addition where we run out of modifier and the distribution of modified species is recorded at each point. The modification status is governed by the relative kinetics of the reaction to modify each cysteine. In a paper by Irvine et al. [111], relative rate constants for each of the 11 modification reactions of the $\alpha$-fragments of MT were calculated and the trend in relative ks was used to interpret the spectra.

In addition to reporting the relative kinetics of the intrinsic cysteine alkylation reaction, this reaction can be modified to probe demetalation through the competition of metals with modifying reagents. By mixing fully metalated $\mathrm{Cd}_{7}-\mathrm{MT} 2 \mathrm{a}$ with excess NEM, Chen et al. were able to observe major $\mathrm{Cd}_{\mathrm{x}} \mathrm{NEM}_{\mathrm{y}}$ species form as the ratio of NEM:MT was increased [120]. Through monitoring the progress of this slower displacement reaction via ESI-MS and subsequent analysis though collision induced dissociation, ion mobility mass spectrometry (MS-CID-IM-MS), they were able to determine the kinetic rate constants of each of the seven displacement reactions and identify the most labile cysteines in MT2a [120]. This approach is novel in its site specificity for probing cysteine accessibility and involvement in metal binding and can help to determine metal binding mechanisms and structural conformations in exquisite detail.

\section{Conclusions}

Structural information regarding MTs has been hard to come by due to its highly dynamic nature in the absence of metal clusters. Recently, advances have been in residue modification mass spectrometry in order to probe the hard-to-characterize structure of apo- and partially metalated MTs. By using different site and cysteine specific alkylation reagents, time dependent ESI-MS, and step-wise "snapshot" ESI-MS, we are beginning to understand the dynamics of the conformers of apo-MT and related species. Recent studies have also highlighted the importance of the apo-MT structure for metalation kinetics. Coupled with other mass spectrometric techniques like IM-MS, the structure of apo-MT once thought to be non-existent is beginning to become clear. We expect increasing resolution in our picture of the structural conformations of metal-free MTs as this technique is more widely adopted and combined with other promising tools for structural elucidation. In addition, these 
methods could be extended to other intrinsically disordered proteins with significant amounts of reactive residues, adding another tool to the toolbox available for structural investigations.

Acknowledgments: We gratefully acknowledge financial support from NSERC through a Canada Graduate Scholarship to Gordon W. Irvine and Discovery Grant (37-2015) and Research Tools and Instrument grants to Martin J. Stillman. We wish to acknowledge Melissa Santolini and Judith Scheller for their recent work with the cysteine modification project.

Author Contributions: Gordon W. Irvine wrote and edited the manuscript with significant input and editing from Martin J. Stillman.

Conflicts of Interest: The authors declare no conflict of interest.

\section{References}

1. Del Gobbo, G.M.; Williams, M.S.; Blakeborough, A. Seismic Performance Assessment of a Code Compliant Multistorey Building. In International Conference on Urban Risks; European Centre on Urban Risk: Lisbon, Portugal, 2016; Volume 1, pp. 1-8.

2. Vašák, M. Advances in metallothionein structure and functions. J. Trace Elem. Med. Biol. 2005, $19,13-17$. [CrossRef] [PubMed]

3. Lindahl, T. Instability and decay of the primary structure of DNA. Nature 1993, 362, 709-715. [CrossRef]

4. Brooks, C. Irony as a Principle of Structure. In Literary Opinion in America; Harper \& Row: New York, NY, USA, 1951; Volume 2.

5. Sumner, J.B. The isolation and crystallization of the enzyme urease preliminary paper. J. Biol. Chem. 1926, 69, 435-441.

6. Kelley, L.A.; Sternberg, M.J. Protein structure prediction on the web: A case study using the phyre server. Nat. Protoc. 2009, 4, 363-371. [CrossRef] [PubMed]

7. Kägi, J.; Himmelhoch, S.; Whanger, P.; Bethune, J.; Vallee, B.L. Equine hepatic and renal metallothioneins purification, molecular weight, amino acid composition, and metal content. J. Biol. Chem. 1974, 249, 3537-3542.

8. Richards, M.P.; Beattie, J.H. Characterization of metallothionein isoforms: Comparison of capillary zone electrophoresis with reversed-phase high-performance liquid chromatography. J. Chromatogr. A 1993, 648, 459-468. [CrossRef]

9. Kägi, J.H.; Vallee, B.L. Metallothionein: A cadmium and zinc-containing protein from equine renal cortex II. Physicochemical properties. J. Biol. Chem. 1961, 236, 2435-2442.

10. Sutherland, D.E.; Stillman, M.J. The "magic numbers" of metallothionein. Metallomics 2011, 3, 444-463. [CrossRef] [PubMed]

11. Gui, Z.; Green, A.R.; Kasrai, M.; Bancroft, G.M.; Stillman, M.J. Sulfur K-edge exafs studies of cadmium-, zinc-, copper-, and silver-rabbit liver metallothioneins. Inorg. Chem. 1996, 35, 6520-6529. [CrossRef]

12. Piccinni, E.; Staudenmann, W.; Albergoni, V.; Gabrieli, R.; James, P. Purification and primary structure of metallothioneins induced by cadmium in the protists tetrahymena pigmentosa and tetrahymena pyriformis. Eur. J. Biochem. 1994, 226, 853-859. [CrossRef]

13. Leiva-Presa, À.; Capdevila, M.; Gonzàlez-Duarte, P. Mercury (II) binding to metallothioneins. Eur. J. Biochem. 2004, 271, 4872-4880. [CrossRef]

14. Acharya, C.; Blindauer, C.A. Unexpected interactions of the cyanobacterial metallothionein smta with uranium. Inorg. Chem. 2016, 55, 1505-1515. [CrossRef]

15. Lecina, J.; Palacios, Ò.; Atrian, S.; Capdevila, M.; Suades, J. Rhenium and technetium tricarbonyl, $\{\mathrm{M}(\mathrm{CO}) 3\}(+)$ $(\mathrm{M}=\mathrm{Tc}, \mathrm{Re})$, binding to mammalian metallothioneins: New insights into chemical and radiopharmaceutical implications. JBIC J. Biol. Inorg. Chem. 2015, 20, 465-474. [CrossRef]

16. Andersen, R.; Wiger, R.; Daae, H.; Eriksen, K. Is the metal binding protein metallothionein present in the coelenterate hydra attenuata? Comp. Biochem. Physiol. Part C Comp. Pharmacol. 1988, 91, 553-557. [CrossRef]

17. Reitzel, A.M.; Sullivan, J.C.; Traylor-Knowles, N.; Finnerty, J.R. Genomic survey of candidate stress-response genes in the estuarine anemone nematostella vectensis. Biol. Bull. 2008, 214, 233-254. [CrossRef]

18. Shinzato, C.; Hamada, M.; Shoguchi, E.; Kawashima, T.; Satoh, N. The repertoire of chemical defense genes in the coral acropora digitifera genome. Zool. Sci. 2012, 29, 510-517. [CrossRef]

19. Elran, R.; Raam, M.; Kraus, R.; Brekhman, V.; Sher, N.; Plaschkes, I.; Chalifa-Caspi, V.; Lotan, T. Early and late response of nematostella vectensis transcriptome to heavy metals. Mol. Ecol. 2014, 23, 4722-4736. [CrossRef] 
20. Davis, J.J.; Hill, H.A.O.; Kurz, A.; Jacob, C.; Maret, W.; Vallee, B.L. A scanning tunneling microscopy study of rabbit metallothionein. Phys. Chem. Commun. 1998, 1, 12-22. [CrossRef]

21. Capdevila, M.; Bofill, R.; Palacios, O.; Atrian, S. State-of-the-art of metallothioneins at the beginning of the 21st century. Coord. Chem. Rev. 2012, 256, 46-62. [CrossRef]

22. Capdevila, M.; Atrian, S. Metallothionein protein evolution: A miniassay. JBIC J. Biol. Inorg. Chem. 2011, 16, 977-989. [CrossRef]

23. Theocharis, S.; Margeli, A.; Klijanienko, J.; Kouraklis, G. Metallothionein expression in human neoplasia. Histopathology 2004, 45, 103-118. [CrossRef]

24. Laukens, D.; Waeytens, A.; de Bleser, P.; Cuvelier, C.; de Vos, M. Human metallothionein expression under normal and pathological conditions: Mechanisms of gene regulation based on in silico promoter analysis. Crit. Rev. Eukaryot. Gene Expr. 2009, 19, 301-317. [CrossRef]

25. Hozumi, I.; Suzuki, J.S.; Kanazawa, H.; Hara, A.; Saio, M.; Inuzuka, T.; Miyairi, S.; Naganuma, A.; Tohyama, C. Metallothionein-3 is expressed in the brain and various peripheral organs of the rat. Neurosci. Lett. 2008, 438, 54-58. [CrossRef]

26. Quaife, C.J.; Findley, S.D.; Erickson, J.C.; Froelick, G.J.; Kelly, E.J.; Zambrowicz, B.P.; Palmiter, R.D. Induction of a new metallothionein isoform (MT-IV) occurs during differentiation of stratified squamous epithelia. Biochemistry 1994, 33, 7250-7259. [CrossRef]

27. Outten, C.E.; O'halloran, T.V. Femtomolar sensitivity of metalloregulatory proteins controlling zinc homeostasis. Science 2001, 292, 2488-2492. [CrossRef]

28. Finney, L.A.; O'halloran, T.V. Transition metal speciation in the cell: Insights from the chemistry of metal ion receptors. Science 2003, 300, 931-936. [CrossRef]

29. Fischbach, M.A.; Lin, H.; Liu, D.R.; Walsh, C.T. How pathogenic bacteria evade mammalian sabotage in the battle for iron. Nat. Chem. Biol. 2006, 2, 132-138. [CrossRef]

30. Dong, G.; Chen, H.; Qi, M.; Dou, Y.; Wang, Q. Balance between metallothionein and metal response element binding transcription factor 1 is mediated by zinc ions. Mol. Med. Rep. 2015, 11, 1582-1586. [CrossRef]

31. Blindauer, C.A.; Leszczyszyn, O.I. Metallothioneins: Unparalleled diversity in structures and functions for metal ion homeostasis and more. Nat. Prod. Rep. 2010, 27, 720-741. [CrossRef]

32. Pinter, T.B.; Stillman, M.J. The zinc balance: Competitive zinc metalation of carbonic anhydrase and metallothionein 1a. Biochemistry 2014, 53, 6276-6285. [CrossRef]

33. Banci, L.; Bertini, I.; Ciofi-Baffoni, S.; Kozyreva, T.; Zovo, K.; Palumaa, P. Affinity gradients drive copper to cellular destinations. Nature 2010, 465, 645-648. [CrossRef]

34. Klaassen, C.D.; LIU, J. Metallothionein transgenic and knock-out mouse models in the study of cadmium toxicity. J. Toxicol. Sci. 1998, 23, 97-102. [CrossRef]

35. Andrews, G.K.; Geiser, J. Expression of the mouse metallothionein-I and-II genes provides a reproductive advantage during maternal dietary zinc deficiency. J. Nutr. 1999, 129, 1643-1648.

36. Waalkes, M.P.; Liu, J.; Goyer, R.A.; Diwan, B.A. Metallothionein-I/II double knockout mice are hypersensitive to lead-induced kidney carcinogenesis. Cancer Res. 2004, 64, 7766-7772. [CrossRef]

37. Petro, A.; Sexton, H.G.; Miranda, C.; Rastogi, A.; Freedman, J.H.; Levin, E.D. Persisting neurobehavioral effects of developmental copper exposure in wildtype and metallothionein 1 and 2 knockout mice. BMC Pharmacol. Toxicol. 2016, 17, 55. [CrossRef]

38. Kadota, Y.; Aki, Y.; Toriuchi, Y.; Mizuno, Y.; Kawakami, T.; Sato, M.; Suzuki, S. Deficiency of metallothionein-1 and-2 genes shortens the lifespan of the 129/Sv mouse strain. Exp. Gerontol. 2015, 66, 21-24. [CrossRef]

39. Qu, W.; Waalkes, M.P. Metallothionein blocks oxidative DNA damage induced by acute inorganic arsenic exposure. Toxicol. Appl. Pharmacol. 2015, 282, 267-274. [CrossRef]

40. Klaassen, C.D.; Liu, J.; Choudhuri, S. Metallothionein: An intracellular protein to protect against cadmium toxicity. Annu. Rev. Pharmacol. Toxicol. 1999, 39, 267-294. [CrossRef]

41. Rani, A.; Kumar, A.; Lal, A.; Pant, M. Cellular mechanisms of cadmium-induced toxicity: A review. Int. J. Environ. Health Res. 2014, 24, 378-399. [CrossRef]

42. Margoshes, M.; Vallee, B.L. A cadmium protein from equine kidney cortex. J. Am. Chem. Soc. 1957, 79, 4813-4814. [CrossRef]

43. Kägi, J.H.; Vallee, B.L. Metallothionein: A cadmium-and zinc-containing protein from equine renal cortex. J. Biol. Chem. 1960, 235, 3460-3465. 
44. Irvine, G.W.; Stillman, M.J. Topographical analysis of as-induced folding of $\alpha$-MT-1a. Biochem. Biophys. Res. Commun. 2013, 441, 208-213. [CrossRef]

45. Ngu, T.T.; Easton, A.; Stillman, M.J. Kinetic analysis of arsenic-metalation of human metallothionein: Significance of the two-domain structure. J. Am. Chem. Soc. 2008, 130, 17016-17028. [CrossRef]

46. Jiang, G.; Gong, Z.; Li, X.-F.; Cullen, W.R.; Le, X.C. Interaction of trivalent arsenicals with metallothionein. Chem. Res. Toxicol. 2003, 16,873-880. [CrossRef]

47. Ngu, T.T.; Dryden, M.D.; Stillman, M.J. Arsenic transfer between metallothionein proteins at physiological ph. Biochem. Biophys. Res. Commun. 2010, 401, 69-74. [CrossRef]

48. Garla, R.; Mohanty, B.P.; Ganger, R.; Sudarshan, M.; Bansal, M.P.; Garg, M.L. Metal stoichiometry of isolated and arsenic substituted metallothionein: PIXE and ESI-MS study. Biometals 2013, 26, 887-896. [CrossRef]

49. Rahman, M.T.; de Ley, M. Arsenic induction of metallothionein and metallothionein induction against arsenic cytotoxicity. Rev. Environ. Contam. Toxicol. 2016, 240, 151-168.

50. Person, R.J.; Ngalame, N.N.O.; Makia, N.L.; Bell, M.W.; Waalkes, M.P.; Tokar, E.J. Chronic inorganic arsenic exposure in vitro induces a cancer cell phenotype in human peripheral lung epithelial cells. Toxicol. Appl. Pharmacol. 2015, 286, 36-43. [CrossRef]

51. Slusser, A.; Zheng, Y.; Zhou, X.D.; Somji, S.; Sens, D.A.; Sens, M.A.; Garrett, S.H. Metallothionein isoform 3 expression in human skin, related cancers and human skin derived cell cultures. Toxicol. Lett. 2015, 232, 141-148. [CrossRef]

52. Garla, R.; Ganger, R.; Mohanty, B.P.; Verma, S.; Bansal, M.P.; Garg, M.L. Metallothionein does not sequester arsenic (III) ions in condition of acute arsenic toxicity. Toxicology 2016, 366, 68-73. [CrossRef]

53. Carpenter, M.C.; Shah, A.S.; DeSilva, S.; Gleaton, A.; Su, A.; Goundie, B.; Croteau, M.L.; Stevenson, M.J.; Wilcox, D.; Austin, R.N. Thermodynamics of $\mathrm{Pb}$ (II) and Zn (II) binding to MT-3, a neurologically important metallothionein. Metallomics 2016, 8, 605-617. [CrossRef]

54. Wezynfeld, N.E.; Stefaniak, E.; Stachucy, K.; Drozd, A.; Płonka, D.; Drew, S.C.; Krężel, A.; Bal, W. Resistance of $\mathrm{Cu}(\mathrm{A} \beta 4-16)$ to copper capture by metallothionein-3 supports a function for the A $\beta 4-42$ peptide as a synaptic cuii scavenger. Angew. Chem. Int. Ed. 2016, 55, 8235-8238. [CrossRef]

55. Lee, S.-J.; Seo, B.-R.; Koh, J.-Y. Metallothionein-3 modulates the amyloid $\beta$ endocytosis of astrocytes through its effects on actin polymerization. Mol. Brain 2015, 8, 84. [CrossRef]

56. Luo, Y.; Xu, Y.; Bao, Q.; Ding, Z.; Zhu, C.; Huang, Z.-X.; Tan, X. The molecular mechanism for human metallothionein-3 to protect against the neuronal cytotoxicity of A $\beta 1-42$ with cu ions. JBIC J. Biol. Inorg. Chem. 2013, 18, 39-47. [CrossRef]

57. Gonzalez-Iglesias, H.; Alvarez, L.; García, M.; Petrash, C.; Sanz-Medel, A.; Coca-Prados, M. Metallothioneins (MTS) in the human eye: A perspective article on the zinc-MT redox cycle. Metallomics 2014, 6, 201-208. [CrossRef]

58. Maret, W. Metallothionein redox biology in the cytoprotective and cytotoxic functions of zinc. Exp. Gerontol. 2008, 43, 363-369. [CrossRef]

59. Krężel, A.; Hao, Q.; Maret, W. The zinc/thiolate redox biochemistry of metallothionein and the control of zinc ion fluctuations in cell signaling. Arch. Biochem. Biophys. 2007, 463, 188-200. [CrossRef]

60. Ryvolova, M.; Krizkova, S.; Adam, V.; Beklova, M.; Trnkova, L.; Hubalek, J.; Kizek, R. Analytical methods for metallothionein detection. Curr. Anal. Chem. 2011, 7, 243-261. [CrossRef]

61. Mehus, A.A.; Muhonen, W.W.; Garrett, S.H.; Somji, S.; Sens, D.A.; Shabb, J.B. Quantitation of human metallothionein isoforms: A family of small, highly conserved, cysteine-rich proteins. Mol. Cell. Proteom. 2014, 13, 1020-1033. [CrossRef]

62. Calderone, V.; Dolderer, B.; Hartmann, H.-J.; Echner, H.; Luchinat, C.; Del Bianco, C.; Mangani, S.; Weser, U. The crystal structure of yeast copper thionein: The solution of a long-lasting enigma. Proc. Natl. Acad. Sci. USA 2005, 102, 51-56. [CrossRef]

63. Robbins, A.; McRee, D.; Williamson, M.; Collett, S.; Xuong, N.; Furey, W.; Wang, B.; Stout, C. Refined crystal structure of CD, Zn metallothionein at 2.0 åresolution. J. Mol. Biol. 1991, 221, 1269-1293.

64. Zangger, K.; ÖZ, G.; Armitage, I.M.; Otvos, J.D. Three-dimensional solution structure of mouse Cd7-metallothionein-1 by homonuclear and heteronuclear nmr spectroscopy. Protein Sci. 1999, 8, 2630-2638. [CrossRef] 
65. Schultze, P.; Wörgötter, E.; Braun, W.; Wagner, G.; Vašák, M.; Kägi, J.H.; Wüthrich, K. Conformation of Cd7-metallothionein-2 from rat liver in aqueous solution determined by nuclear magnetic resonance spectroscopy. J. Mol. Biol. 1988, 203, 251-268. [CrossRef]

66. Messerle, B.A.; Schäffer, A.; Vašák, M.; Kägi, J.H.; Wüthrich, K. Three-dimensional structure of human $113 \mathrm{Cd} 7$ metallothionein-2 in solution determined by nuclear magnetic resonance spectroscopy. J. Mol. Biol. 1990, 214, 765-779. [CrossRef]

67. Irvine, G.W.; Pinter, T.B.; Stillman, M.J. Defining the metal binding pathways of human metallothionein 1a: Balancing zinc availability and cadmium seclusion. Metallomics 2016, 8, 71-81. [CrossRef]

68. Good, M.; Hollenstein, R.; Sadler, P.J.; Vasak, M. Cadmium-113 NMR studies on metal-thiolate cluster formation in rabbit cadmium (II) metallothionein: Evidence for a PH dependence. Biochemistry 1988, 27, 7163-7166. [CrossRef]

69. Sutherland, D.E.; Willans, M.J.; Stillman, M.J. Single domain metallothioneins: Supermetalation of human MT-1a. J. Am. Chem. Soc. 2012, 134, 3290-3299. [CrossRef]

70. Rupp, H.; Weser, U. Circular dichroism of metallothioneins: A structural approach. Biochim. Biophys. Acta Protein Struct. 1978, 533, 209-226. [CrossRef]

71. Ejnik, J.; Robinson, J.; Zhu, J.; Försterling, H.; Shaw, C.F.; Petering, D.H. Folding pathway of apo-metallothionein induced by $\mathrm{Zn}^{2+}, \mathrm{Cd}^{2+}$ and $\mathrm{Co}^{2+}$. J. Inorg. Biochem. 2002, 88, 144-152. [CrossRef]

72. Presta, A.; Green, A.R.; Zelazowski, A.; Stillman, M.J. Copper binding to rabbit liver metallothionein. Eur. J. Biochem. 1995, 227, 226-240. [CrossRef]

73. Stillaman, M.J.; Zelazowski, A.S.; Szymanska, J.; Gasyna, Z. Luminescent metallothioneins: Emission properties of copper, silver, gold and platinum complexes of MT. Inorg. Chim. Acta 1989, 161, 275-279. [CrossRef]

74. Hartmann, H.-J.; Li, Y.-J.; Weser, U. Analogous copper (I) coordination in metallothionein from yeast and the separate domains of the mammalian protein. Biometals 1992, 5, 187-191. [CrossRef]

75. Grandori, R. Origin of the conformation dependence of protein charge-state distributions in electrospray ionization mass spectrometry. J. Mass Spectrom. 2003, 38, 11-15. [CrossRef]

76. Rodriguez, A.D.; Dunn, S.D.; Konermann, L. ATP-induced dimerization of the F0F1 $\varepsilon$ subunit from bacillus PS3: A hydrogen exchange-mass spectrometry study. Biochemistry 2014, 53, 4072-4080. [CrossRef]

77. Witze, E.S.; Old, W.M.; Resing, K.A.; Ahn, N.G. Mapping protein post-translational modifications with mass spectrometry. Nat. Methods 2007, 4, 798-806. [CrossRef]

78. Konermann, L.; Vahidi, S.; Sowole, M.A. Mass spectrometry methods for studying structure and dynamics of biological macromolecules. Anal. Chem. 2013, 86, 213-232. [CrossRef]

79. Weerapana, E.; Wang, C.; Simon, G.M.; Richter, F.; Khare, S.; Dillon, M.B.; Bachovchin, D.A.; Mowen, K.; Baker, D.; Cravatt, B.F. Quantitative reactivity profiling predicts functional cysteines in proteomes. Nature 2010, 468, 790-795. [CrossRef]

80. O'Halloran, T.V.; Culotta, V.C. Metallochaperones, an intracellular shuttle service for metal ions. J. Biol. Chem. 2000, 275, 25057-25060. [CrossRef]

81. Zhou, N.E.; Kay, C.M.; Hodges, R.S. Disulfide bond contribution to protein stability: Positional effects of substitution in the hydrophobic core of the two-stranded $\alpha$-helical coiled-coil. Biochemistry 1993, 32, 3178-3187. [CrossRef]

82. Bernardim, B.; Cal, P.M.; Matos, M.J.; Oliveira, B.L.; Martínez-Sáez, N.; Albuquerque, I.S.; Perkins, E.; Corzana, F.; Burtoloso, A.C.; Jiménez-Osés, G. Stoichiometric and irreversible cysteine-selective protein modification using carbonylacrylic reagents. Nat. Commun. 2016, 7. [CrossRef]

83. Yang, J.; Gupta, V.; Carroll, K.S.; Liebler, D.C. Site-specific mapping and quantification of protein S-sulfenylation in cells. Nat. Commun. 2014, 5, 4776. [CrossRef]

84. Dayon, L.; Roussel, C.; Girault, H.H. On-line electrochemical tagging of free cysteines in peptides during nanospray ionisation mass spectrometry: An overview. CHIMIA Int. J. Chem. 2004, 58, 204-207. [CrossRef]

85. Diedrich, J.K.; Julian, R.R. Site-selective fragmentation of peptides and proteins at quinone-modified cysteine residues investigated by ESI-MS. Anal. Chem. 2010, 82, 4006-4014. [CrossRef]

86. Diedrich, J.K.; Julian, R.R. Site-specific radical directed dissociation of peptides at phosphorylated residues. J. Am. Chem. Soc. 2008, 130, 12212-12213. [CrossRef]

87. Irvine, G.W.; Summers, K.L.; Stillman, M.J. Cysteine accessibility during as 3+ metalation of the $\alpha$-and $\beta$-domains of recombinant human MT-1a. Biochem. Biophys. Res. Commun. 2013, 433, 477-483. [CrossRef] 
88. Ngu, T.T.; Stillman, M.J. Arsenic binding to human metallothionein. J. Am. Chem. Soc. 2006, 128, 12473-12483. [CrossRef]

89. Irvine, G.W.; Stillman, M.J. Cadmium binding mechanisms of isolated domains of human MT isoform 1a: Non-cooperative terminal sites and cooperative cluster sites. J. Inorg. Biochem. 2016, 158, 115-121. [CrossRef]

90. Limson, J.; Nyokong, T. Voltammetric behavior of cysteine and metallothionein on cobalt (II) tetrasulfonated phthalocyanine modified glassy carbon electrodes. Electroanalysis 1997, 9, 255-260. [CrossRef]

91. Chen, K.; Lu, G.; Chang, J.; Mao, S.; Yu, K.; Cui, S.; Chen, J. Hg (II) ion detection using thermally reduced graphene oxide decorated with functionalized gold nanoparticles. Anal. Chem. 2012, 84, 4057-4062. [CrossRef]

92. Qian, Q.-M.; Wang, Y.-S.; Yang, H.-X.; Xue, J.-H.; Liu, L.; Zhou, B.; Wang, J.-C.; Yin, J.-C.; Wang, Y.-S. Colorimetric detection of metallothioneins using a thymine-rich oligonucleotide-Hg complex and gold nanoparticles. Anal. Biochem. 2013, 436, 45-52. [CrossRef]

93. Summers, K.L.; Mahrok, A.K.; Dryden, M.D.; Stillman, M.J. Structural properties of metal-free apometallothioneins. Biochem. Biophys. Res. Commun. 2012, 425, 485-492. [CrossRef]

94. Stillman, M.; Cai, W.; Zelazowski, A. Cadmium binding to metallothioneins. Domain specificity in reactions of $\alpha$ and $\beta$ fragments, apometallothionein, and zinc metallothionein with $\mathrm{Cd}^{2+}$. J. Biol. Chem. 1987, 262, 4538-4548.

95. Li, H.; Otvos, J.D. 111Cd NMR studies of the domain specificity of $\mathrm{Ag}^{+}$and $\mathrm{Cu}^{+}$binding to metallothionein. Biochemistry 1996, 35, 13929-13936. [CrossRef]

96. Pinter, T.B.; Stillman, M.J. Putting the pieces into place: Properties of intact zinc metallothionein 1a determined from interaction of its isolated domains with carbonic anhydrase. Biochem. J. 2015, 471, 347-356. [CrossRef]

97. Artells, E.; Palacios, O.; Capdevila, M.; Atrian, S. In vivo-folded metal-metallothionein 3 complexes reveal the $\mathrm{Cu}$-thionein rather than $\mathrm{Zn}$-thionein character of this brain-specific mammalian metallothionein. FEBS J. 2014, 281, 1659-1678. [CrossRef]

98. Pinter, T.B.; Irvine, G.W.; Stillman, M.J. Domain selection in metallothionein 1a: Affinity-controlled mechanisms of zinc binding and cadmium exchange. Biochemistry 2015, 54, 5006-5016. [CrossRef]

99. Palumaa, P.; Njunkova, O.; Pokras, L.; Eriste, E.; Jörnvall, H.; Sillard, R. Evidence for non-isostructural replacement of $\mathrm{Zn}^{2+}$ with $\mathrm{Cd}^{2+}$ in the $\beta$-domain of brain-specific metallothionein-3. FEBS Lett. 2002, 527, 76-80. [CrossRef]

100. Tomas, M.; Pagani, M.; Andreo, C.; Capdevila, M.; Atrian, S.; Bofill, R. Sunflower metallothionein family characterisation. Study of the Zn (II)- and Cd (II)-binding abilities of the HAMT1 and HAMT2 isoforms. J. Inorg. Biochem. 2015, 148, 35-48. [CrossRef]

101. Palacios, Ò.; Atrian, S.; Capdevila, M. Zn- and Cu-thioneins: A functional classification for metallothioneins? JBIC J. Biol. Inorg. Chem. 2011, 16, 991. [CrossRef]

102. Ostrakhovitch, E.; Song, Y.; Cherian, M. Basal and copper-induced expression of metallothionein isoform 1, 2 and 3 genes in epithelial cancer cells: The role of tumor suppressor p53. J. Trace Elem. Med. Biol. 2016, 35, 18-29. [CrossRef]

103. Chen, S.-H.; Russell, W.K.; Russell, D.H. Combining chemical labeling, bottom-up and top-down ion-mobility mass spectrometry to identify metal-binding sites of partially metalated metallothionein. Anal. Chem. 2013, 85, 3229-3237. [CrossRef]

104. Thirumoorthy, N.; Sunder, A.S.; Kumar, K.M.; Ganesh, G.; Chatterjee, M. A review of metallothionein isoforms and their role in pathophysiology. World J. Surg. Oncol. 2011, 9, 54. [CrossRef]

105. Pérez-Rafael, S.; Monteiro, F.; Dallinger, R.; Atrian, S.; Palacios, Ò.; Capdevila, M. Cantareus aspersus metallothionein metal binding abilities: The unspecific cacd/cumt isoform provides hints about the metal preference determinants in metallothioneins. Biochim. Biophys. Acta Proteins Proteom. 2014, 1844, 1694-1707. [CrossRef]

106. Robinson, N.J.; Tommey, A.M.; Kuske, C.; Jackson, P.J. Plant metallothioneins. Biochem. J. 1993, $295,1$. [CrossRef]

107. Pérez-Rafael, S.; Atrian, S.; Capdevila, M.; Palacios, Ò. Differential ESI-MS behaviour of highly similar metallothioneins. Talanta 2011, 83, 1057-1061. [CrossRef]

108. Scheller, J.S.; Irvine, G.W.; Wong, D.L.; Hartwig, A.; Stillman, M. Stepwise copper(I) binding to metallothionein: A mixed cooperative and non-cooperative mechanism. Metallomics 2017. [CrossRef] 
109. Singh, P.; Panchaud, A.; Goodlett, D.R. Chemical cross-linking and mass spectrometry as a low-resolution protein structure determination technique. Anal. Chem. 2010, 82, 2636-2642. [CrossRef]

110. Chen, S.-H.; Chen, L.; Russell, D.H. Metal-induced conformational changes of human metallothionein-2A: A combined theoretical and experimental study of metal-free and partially metalated intermediates. J. Am. Chem. Soc. 2014, 136, 9499-9508. [CrossRef]

111. Irvine, G.W.; Duncan, K.E.; Gullons, M.; Stillman, M.J. Metalation kinetics of the human $\alpha$-metallothionein 1a fragment is dependent on the fluxional structure of the apo-protein. Chem. Eur. J. 2015, 21, 1269-1279. [CrossRef]

112. Jha, S.K.; Udgaonkar, J.B. Exploring the cooperativity of the fast folding reaction of a small protein using pulsed thiol labeling and mass spectrometry. J. Biol. Chem. 2007, 282, 37479-37491. [CrossRef]

113. Gould, N.S.; Evans, P.; Martínez-Acedo, P.; Marino, S.M.; Gladyshev, V.N.; Carroll, K.S.; Ischiropoulos, H. Site-specific proteomic mapping identifies selectively modified regulatory cysteine residues in functionally distinct protein networks. Chem. Biol. 2015, 22, 965-975. [CrossRef]

114. Wiggins, B.; Liu-Shin, L.; Yamaguchi, H.; Ratnaswamy, G. Characterization of cysteine-linked conjugation profiles of immunoglobulin G1 and immunoglobulin G2 antibody-drug conjugates. J. Pharm. Sci. 2015, 104, 1362-1372. [CrossRef]

115. Alegre-Cebollada, J.; Kosuri, P.; Giganti, D.; Eckels, E.; Rivas-Pardo, J.A.; Hamdani, N.; Warren, C.M.; Solaro, R.J.; Linke, W.A.; Fernández, J.M. S-glutathionylation of cryptic cysteines enhances titin elasticity by blocking protein folding. Cell 2014, 156, 1235-1246. [CrossRef]

116. Li, Y.; Jongberg, S.; Andersen, M.L.; Davies, M.J.; Lund, M.N. Quinone-induced protein modifications: Kinetic preference for reaction of 1, 2-benzoquinones with thiol groups in proteins. Free Radic. Biol. Med. 2016, 97, 148-157. [CrossRef]

117. Cal, P.M.; Bernardes, G.J.; Gois, P.M. Cysteine-selective reactions for antibody conjugation. Angew. Chem. Int. Ed. 2014, 53, 10585-10587. [CrossRef]

118. Smythe, C. The reaction of iodoacetate and of iodoacetamide with various sulfhydryl groups, with urease, and with yeast preparations. J. Biol. Chem. 1936, 114, 601-612.

119. Irvine, G.W.; Santolini, M.; Stillman, M.J. Selective cysteine modification of metal-free human metallothionein 1a and its isolated domain fragments: Solution structural properties revealed via ESI-MS. Protein Sci. 2017. [CrossRef]

120. Chen, S.-H.; Russell, D.H. Reaction of human Cd7 metallothionein and N-ethylmaleimide: Kinetic and structural insights from electrospray ionization mass spectrometry. Biochemistry 2015, 54, 6021-6028. [CrossRef]

(C) 2017 by the authors. Licensee MDPI, Basel, Switzerland. This article is an open access article distributed under the terms and conditions of the Creative Commons Attribution (CC BY) license (http:/ / creativecommons.org/licenses/by/4.0/). 